\title{
Sol-gel preparation and properties of amorphous iron-containing aluminosilicate
}

\author{
(C) Lyubov V. Furda, * Evgeniya A. Tarasenko, \\ Sofya N. Dudina, and Olga E. Lebedeva ${ }^{+}$ \\ Department of General Chemistry. Institute of Pharmacy, Chemistry and Biology. \\ Belgorod State National Research University. Pobedy St., 85. Belgorod, 308015. Russia. \\ Phone: +7 (4722) 30-11-66.E-mail: OLebedeva@bsu.edu.ru
}

\begin{abstract}
*Supervising author; ${ }^{+}$Corresponding author
Keywords: iron-containing aluminosilicates, sol-gel synthesis, porosity, specific surface area, acidbase properties.
\end{abstract}

\begin{abstract}
The objective of the present study includes a modification of synthetic aluminosilicate with iron cations and an estimation of the modificator influence at structure and properties of the aluminosilicate. The ironcontaining aluminosilicate $(\mathrm{Si} / \mathrm{Al}=4.72)$ with an $\mathrm{Al} / \mathrm{Fe}$ molar ratio of 5:1 was prepared by the sol-gel method at $\mathrm{pH}=1-2$. Amorphous aluminosilicate $(\mathrm{Si} / \mathrm{Al}=4.72)$, which was synthesized by analogous procedure, was applied as a reference sample. By scanning electron microscopy, it was found that the powders had particles of 1-20 micrometers in size. The results of low-temperature adsorption-thermal desorption of nitrogen showed that the modification with $\mathrm{Fe}^{3+}$ ions affected the specific surface area and porosity of the material under study. The iron-containing sample has a higher specific surface area and pore volume comparing to the initial aluminosilicate. The Hammett indicator method was used to evaluate the surface centers of the samples. It was found that the materials under study were characterized by the presence of active sites with $p K_{a}^{x}$ values in the range from -4.4 to 12.8 with a pronounced maximum at $p K_{a}{ }^{x}=1.02$. For an iron-containing sample, the concentration of acid sites significantly decreases at $p K_{a}^{x}=1.02$, while at $p K_{a}^{x} 0.80,1.03,2.10,2.50,4.10$, $5.00,8.00$, and 12.80, an increase in the number of acid sites is observed. The values of the Hammett function are practically the same for the studied samples and characterizes them as materials of medium acidity. For iron-containing aluminosilicate, the larger number of active sites was noted, it amounted to $313.5 \mathrm{mmol} / \mathrm{g}$.
\end{abstract}

\section{References}

[1] A.I. Khatsrinov, A.V. Kornilov, T.Z. Lygina et al. Inorganic sorbents based on modified natural calciumand iron-containing aluminosilicates. Inorg Mater. 2019. Vol.55. No.11. P.1138-1145. DOI:10.1134/S0020168519110062

[2] I.L. Botto, M.J. Gonzalez, D. Gazzolli, E.L. Soto. Iron activation of natural aluminosilicates to remove arsenic from groundwater. J. Environ. Sci. Eng. A. 2013. No.2. P.744-752.

[3] A.J.J. Koekkoek, H. Xin, Q. Yang, C. Li, E.J.M. Hensen. Hierarchically structured Fe/ZSM-5 as catalysts for the oxidation of benzene to phenol. Microporous Mesoporous Mater. 2011. Vol.145. P.172-181. DOI:10.1016/j.micromeso.2011.05.013

[4] C. Hammond, M.M. Forde, M.H. Rahim, A. Thetford et al. Direct catalytic conversion of methane to methanol in an aqueous medium by using copper-promoted Fe-ZSM-5. Angew. Chem. Int. Ed. 2012. Vol.51. P.5129-5133. DOI:10.1002/anie.201108706

[5] X. Shi, F. Liu, L. Xie, W. Shan, H. He. $\mathrm{NH}_{3}$-SCR performance of fresh and hydrothermally aged fe-zsm5 in standard and fast selective catalytic reduction reactions. Environ. Sci. Technol. 2013. Vol.47. No.7. P.3293-3298. DOI:10.1021/es304421v

[6] N. Richards, E. Nowicka, J.H. Carter, D.J. Morgan, N.F. Dummer, S. Golunski, G.J. Hutchings. Investigating the Influence of $\mathrm{Fe}$ speciation on $\mathrm{N}_{2} \mathrm{O}$ decomposition over $\mathrm{Fe}-\mathrm{ZSM}-5$ catalysts. Top. Catal. 2018. Vol.61. No.18-19. P.1983-1992. DOI:10.1007/s11244-018-1024-0

[7] G. Li, E.A. Pidko, I.A.W. Filot, R.A. Santen, C. Li, E.J.M. Hensen. Catalytic properties of extraframework iron-containing species in ZSM-5 for $\mathrm{N}_{2} \mathrm{O}$ decomposition. J. Catal. 2013. Vol.308. P.386-397. DOI:10.1016/j.jcat.2013.08.010 
SOL-GEL PREPARATION AND PROPERTIES OF AMORPHOUS IRON-CONTAINING ALUMINOSILICATE 102-107

[8] S. Haldar, S. Koner Iron-containing mesoporous aluminosilicate catalyzed direct alkenylation of phenols: Facile synthesis of 1,1-diarylalkenes. Beilstein J. Org. Chem. 2013. Vol.9. No.1. P.49-55. DOI:10.3762/bjoc.9.6

[9] S. Haldar, S. Koner. Iron-containing mesoporous aluminosilicate: a highly active and reusable heterogeneous catalyst for hydroarylation of styrenes. J. Org. Chem. 2010. Vol.75. No.17. P.6005-6008. DOI:10.1021/jo100803y

[10] A. Wingen, N. Anastasievic, A. Hollnagel, D. Werner, F. Schüth. Fe-MCM-41 as a catalyst for sulfur dioxide oxidation in highly concentrated gases. J. Catal. 2000. Vol.193. No.2. P.248-254. DOI:10.1006/jcat.2000.2896

[11] I. Khan, K. Nomura, E. Kuzmann, Z. Homonnay, K. Sinko, M. Ristic, S. Krehula, S. Music, S. Kubuki Photo-Fenton catalytic ability of iron-containing aluminosilicate glass prepared by sol-gel method. $J$. Alloys Compd. 2020. Vol.816. 153227. DOI:10.1016/j.jallcom.2019.153227

[12] E.V. Karlova, E.S. Podieelnikova, V.P. Lunichkina, T.V. Kon'kova. Porous nanomaterials based on $\mathrm{SiO}_{2}-\mathrm{Al}_{2} \mathrm{O}_{3}$ for purification water from the dyes. Advances in Chemistry and Chemical Technology. 2016. Vol.XXX. No.3. P.72-74. (russian)

[13] T.V. Kon'kova, M.G. Gordienko, M.B. Alekhina, N.V. Menshutina, S.D. Kirik. Mesoporous silica based catalysts for oxidation of azo dyes in wastewater. Catal. Ind. 2015. Vol.15. No.6. P.56-61. DOI: 10.18412/1816-0387-2015-6-56-61

[14] E.T. Dashinamzhilova. Obtaining iron-aluminosilicate catalyst from monmorillonite clay and iron hydroxocomplexes. The Buryat State University Bulletin Chemistry. Physics. 2014. No.3. P.27-29. (russian)

[15] L.V. Furda, E.A. Tarasenko, S.N. Dudina, and O.E. Lebedeva. Effect of acidity on the properties of silica-aluminas synthesized by sol-gel method. Butlerov Communications. 2020. Vol.63. No.7. P.126132. DOI:10.37952/ROI-jbc-01/20-63-7-126

[16] K. Tanabe Solid acids and base. Their catalytic properties. Academic press, New York-London. 1970. $183 \mathrm{p}$.

[17] S.J. Gregg, K.S.W Sing. Adsorption, Surface Area, and Porosity. Academic press. 1991. 303p. 